\title{
The histone methyltransferase EZH2, an oncogene common to benign and malignant parathyroid tumors
}

\author{
Jessica Svedlund, Elham Barazeghi, Peter Stålberg, Per Hellman, Göran Åkerström, \\ Peyman Björklund and Gunnar Westin
}

Department of Surgical Sciences, Endocrine Unit, Uppsala University, Uppsala University Hospital, Entrance 70, 3 tr, SE-751 85 Uppsala, Sweden

\begin{abstract}
Primary hyperparathyroidism (pHPT) resulting from parathyroid tumors is a common endocrine disorder with incompletely understood etiology. In renal failure, secondary hyperparathyroidism (sHPT) occurs with multiple tumor development as a result of calcium and vitamin $D$ regulatory disturbance. The aim of this study was to investigate a potential role of the histone 3 lysine 27 methyltransferase EZH2 in parathyroid tumorigenesis. Parathyroid tumors from patients with pHPT included adenomas and carcinomas. Hyperplastic parathyroid glands from patients with HPT secondary to uremia and normal parathyroid tissue specimens were included in this study. Quantitative RT-PCR, western blotting, bisulfite pyrosequencing, colony formation assay, and RNA interference were used. $E Z H 2$ was overexpressed in a subset of the benign and in all malignant parathyroid tumors as determined by quantitative RT-PCR and western blotting analyses. Overexpression was explained by EZH2 gene amplification in a large fraction of tumors. EZH2 depletion by RNA interference inhibited SHPT-1 parathyroid cell line proliferation as determined by tritiumthymidine incorporation and colony formation assays. EZH2 depletion also interfered with the Wnt/ $\beta$-catenin signaling pathway by increased expression of growth-suppressive AXIN2, a negative regulator of $\beta$-catenin stability. Indeed, EZH2 contributed to the total level of aberrantly accumulated transcriptionally active (nonphosphoylated) $\beta$-catenin in the parathyroid tumor cells. To our knowledge EZH2 gene amplification presents the first genetic aberration common to parathyroid adenomas, secondary hyperplastic parathyroid glands, and parathyroid carcinomas. This supports the possibility of a common pathway in parathyroid tumor development.
\end{abstract}

Correspondence should be addressed to $\mathrm{G}$ Westin Email gunnar.westin@surgsci.uu.se
Endocrine-Related Cancer (2014) 21, 231-239

\section{Introduction}

Parathyroid disease with hypersecretion of parathyroid hormone and generally also hypercalcemia occurs in primary hyperparathyroidism ( $\mathrm{pHPT}$ ), due to growth regulatory disturbance in the parathyroid glands. pHPT is caused by a single, benign adenoma in $\sim 85 \%$ of cases and parathyroid hyperplasia or multiple adenomas in

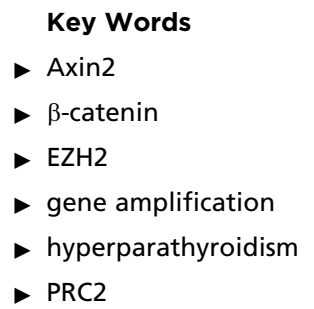

$\sim 15 \%$, and very rarely by parathyroid carcinoma $(<1 \%)$. In renal failure, secondary hyperparathyroidism (sHPT) occurs with multiple tumor development as a result of calcium and vitamin D regulatory disturbance (Marx 2000, Åkerström \& Hellman 2004, Westin et al. 2009, Sharretts $\&$ Simonds 2010). Overexpression of the gene cyclin 
D1 (CCND1) has been demonstrated in pHPT tumors (20-40\%), due to gene translocation and oncogene activation (8\%) and to other unknown mechanisms. Also secondary hyperplastic parathyroid glands (31\%) and parathyroid carcinomas (90\%) have been shown to overexpress cyclin D1 (Westin et al. 2009, Sharretts \& Simonds 2010). CCND1 constitutes a target gene for the Wnt/ $\beta$-catenin signaling pathway and in the absence of gene translocation, overexpression may in part be explained by pathway activation through aberrant accumulation of transcriptionally active (nonphosphorylated) $\beta$-catenin in the cytoplasm/nucleus (Shtutman et al. 1999, Lin et al. 2000, Björklund et al. 2007a, Westin et al. 2009). By immunohistochemical analysis, accumulation of total $\beta$-catenin has been observed in one study, as a frequent event in parathyroid adenomas and secondary hyperplastic parathyroid glands (Björklund et al. 2007b). Such accumulation has not been observed applying several other protocols, as recently summarized in Costa-Guda \& Arnold (2013). Using western blotting analysis and a specific antibody (van Noort et al. 2002), the transcriptionally active (nonphosphorylated) form of $\beta$-catenin was found to be accumulated in parathyroid adenomas and secondary hyperplastic parathyroid glands, strongly implying activation of the $\mathrm{Wnt} / \beta$-catenin signaling pathway (Björklund et al. 2007b, Clevers \& Nusse 2012). The accumulation of active $\beta$-catenin involved an aberrantly spliced internally truncated Wnt coreceptor LRP5. siRNA to LRP5 was shown to reduce the nonphosphorylated active $\beta$-catenin level, transcriptional activation by $\beta$-catenin, and inhibited parathyroid tumor cell growth in vitro and in a xenograft SCID mouse model (Björklund et al. 2007c). The Wnt/ß-catenin signaling pathway has been shown recently to be activated also in parathyroid carcinomas, by aberrant accumulation of nonphosphorylated active $\beta$-catenin. This was caused by inactivation of the APC tumor suppressor gene, likely by promoter DNA methylation (Svedlund et al. 2010). Furthermore, inactivating somatic hereditary hyperparathyroidism type 2 (HRPT2 (CDC73)) gene mutations are common in parathyroid carcinoma and may contribute to cyclin D1 overexpression (Woodard et al. 2005, Westin et al. 2009, Sharretts \& Simonds 2010). Somatic inactivation of the multiple endocrine neoplasia type 1 (MEN1) tumor suppressor gene is frequently observed $(\sim 35 \%)$ in parathyroid adenomas (Lemos \& Thakker 2008, Cromer et al. 2012, Newey et al. 2012).

Recently, it was demonstrated that the HIC1 tumor suppressor gene was generally underexpressed in parathyroid adenomas and secondary hyperplastic parathyroid glands and in parathyroid carcinomas (Svedlund et al. 2012). It was suggested that this involved repressive histone modification H3K27me2/3 rather than DNA methylation. Enhancer of zeste homolog 2 (EZH2) is the enzymatic part of the polycomb repressive complex 2 (PRC2), which is involved in many processes such as cell differentiation, proliferation, cell identity, and stem cell plasticity. PRC2 consists of several components, among them EED and SUZ12 promote PRC2 assembly and contribute to the H3K27 methyltransferase activity of EZH2 (O'Meara \& Simon 2012). EZH2 is highly expressed in many solid tumors, it is considered to be an oncogene and amplification of $E Z H 2$ has been observed in several cancers (Bracken et al. 2003, Saramaki et al. 2006). In lymphoma, heterozygous missense mutations at amino acid Y641 caused higher catalytic efficiency. In contrast, inactivating EZH2 mutations have been found in myeloid neoplasms, supporting a tumor suppressor function (Chase \& Cross 2011, Margueron \& Reinberg 2011, Chang \& Hung 2012). Recently, a link was established between EZH2 and Wnt/ $\beta$-catenin signaling in the development of hepatocellular carcinoma (Cheng et al. 2011). EZH2 was shown to mediate epigenetic repression of several Wnt antagonists, including the growth-suppressive Axin2 which is known to negatively regulate the level of cytoplasmic $\beta$-catenin in the absence of Wnt ligand (Cheng et al. 2011, Clevers \& Nusse 2012). EZH2 may also interact directly with $\beta$-catenin as has been demonstrated in breast cancer (Shi et al. 2007, Li et al. 2009). In this study, we investigated a possible role of EZH2 in parathyroid tumorigenesis.

\section{Materials and methods}

\section{Tissue specimens}

Parathyroid carcinomas $(n=5)$, adenomas $(n=28)$, and hyperplastic parathyroid glands secondary to uremia $(n=16)$ from patients with pHPT and sHPT were acquired from patients diagnosed and operated upon in the clinical routine at Uppsala University Hospital and Martin Luther University of Halle-Wittenberg. Normal parathyroid tissue was obtained from glands inadvertently removed in conjunction with thyroid surgery where autotransplantation was not required $(n=1)$ or as normal parathyroid gland biopsies in patients subjected to parathyroidectomy $(n=4)$. The diagnosis of parathyroid carcinoma was unequivocal due to occurrence of metastases at diagnosis or follow-up. All tissues were intraoperatively snap frozen and cryosections were used in the analyses. Informed consent and approval of ethical committee was achieved.

Published by Bioscientifica Ltd. 


\section{Bisulfite treatment and pyrosequencing}

Total DNA was extracted using AllPrep DNA/RNA Mini Kit (Qiagen) and bisulfite treatment was performed on $400 \mathrm{ng}$ DNA using the EpiTect Bisulfite Kit (Qiagen) according to the manufacturer's instructions. Before pyrosequencing, a PCR was carried out with EZH2 promoter primers: F, 5'-GTATTTTGAGTGGGGTTGGTT-3'; R, 5'-CCCCCCAACCCAATCAAA-3' (biotin labeled); sequencing primer, 5'-GTTAGGAGGGTTTTGTGATTGGA-3'; sequence analyzed, YGGGYGTTYGTTTYGYGTTTYGTTAATYGGGGYGGYGTTT.

The PCR included HotStarTaq Plus Master Mix (Qiagen), $10 \mathrm{pmol}$ of each primer and bisulfite-treated DNA as template. PCR was carried out with an initial denaturation at $95^{\circ} \mathrm{C}$ for $15 \mathrm{~min}$, followed by 45 cycles at $94{ }^{\circ} \mathrm{C}$ for $30 \mathrm{~s}, 50^{\circ} \mathrm{C}$ for $30 \mathrm{~s}, 72^{\circ} \mathrm{C}$ for $30 \mathrm{~s}$, and completed at $72{ }^{\circ} \mathrm{C}$ for $10 \mathrm{~min}$. Pyrosequencing was done using $20 \mu \mathrm{l}$ PCR product with the PyroMark Q24 system (Qiagen) according to manufacturer's instructions. The assay was validated to distinguish equal amplification of unmethylated and methylated DNA. This was done by analyzing a dilution series of bisulfite-treated CpGenome Universal, Methylated DNA (Millipore, Billerica, MA, USA; 100\% methylated) and placenta DNA ( $\sim \%$ methylated).

\section{RNA extraction and quantitative RT-PCR}

DNA-free total RNA was extracted from pHPT tumors $(n=28)$, sHPT tumors $(n=16)$, parathyroid carcinoma $(n=5)$, and normal parathyroid tissue $(n=5)$ using AllPrep DNA/RNA Mini Kit and RNase-Free DNase Set (Qiagen) according to the manufacturer's instructions. Successful DNase-treatments were established by PCR analysis of all RNA preparations. RT of total DNA-free RNA was carried out with random hexamer primers using the RevertAid First, strand cDNA Synthesis Kit (Thermo Fisher Scientific, Waltham, MA, USA) according to the manufacturer's instructions. Quantitative RT-PCR was carried out on StepOnePlus Real-Time PCR Systems (Applied Biosystems, Foster City, CA, USA) using Maxima Probe/ROX qPCR Master Mix (Thermo Scientific) and Applied Biosystems TaqMan assays for EZH2 (Hs01016789_m1), SUZ12 (Hs00248742_m1), EED (Hs00537777_m1), LRP5 (Hs_00182031_m1), AXIN2 (Hs_00610344_m1), CYCLIN D1 (Hs00765553_m1), and GAPDH (Hs02758991_g1). Each cDNA sample was analyzed in triplicate.

\section{Copy-number variation}

Total DNA was extracted using AllPrep DNA/RNA Mini Kit (Qiagen). Copy-number variation was determined using Applied Biosystems TaqMan copy-number assays for EZH2 (Hs02508122_cn and Hs02941342_cn) and RNase $P$ reference (4401631) together with Maxima Probe/ROX qPCR Master Mix (Thermo Scientific) according to the manufacturer's instructions. The samples were run on StepOnePlus Real-Time PCR Systems and analyzed using CopyCaller v2.0 (Applied Biosystems). Each DNA sample was analyzed in quadruplicates with multiple runs and EZH2 amplification was considered when both assays demonstrated this. DNA from placenta and normal parathyroid tissue were used as reference. Both EZH2 PCR assays correctly detected four gene copies of chromosomal DNA from a control cell line with four EZH2 gene copies (NA12519; Corriell Institute for Medical Research, Camden, NJ, USA).

\section{Cell culture and transfection}

sHPT-1 parathyroid tumor cells $\left(2 \times 10^{5}\right)$ were distributed onto $35-\mathrm{mm}$ dishes in DMEM/10\% fetal bovine serum (Sigma) and transfected in triplicates using Interferin siRNA transfection reagent (Polyplus Transfection; SAS, Illkirch, France). EZH2 siRNA (HSS103462, Invitrogen), LRP5 siRNA (sc-43900, Santa Cruz), and control nonsilencing siRNA (Qiagen) were transfected using 20 pmol. The cells were harvested after $120 \mathrm{~h}$ and RNA/protein was extracted. The cells were transfected for $48 \mathrm{~h}$ and then transfected again and further incubated for $72 \mathrm{~h}$ (Svedlund et al. 2012).

\section{Cell viability, ${ }^{3} \mathrm{H}$-thymidine incorporation, and apoptosis}

sHPT-1 parathyroid tumor cells were transfected with siRNA to $E Z H 2$ (see above). The cell viability was measured after $2 \mathrm{~h}$ of incubation with the cell-proliferation reagent WST-1 (Roche Molecular Biochemicals), according to the manufacturer's instructions. For ${ }^{3} \mathrm{H}$-thymidine incorporation, $2 \mu \mathrm{l}^{3} \mathrm{H}$-thymidine/well were added $12 \mathrm{~h}$ before harvest (NET027250UC from PerkinElmer, Norwalk, CT, USA). The medium was then aspirated and unspecifically incorporated ${ }^{3} \mathrm{H}$-thymidine was precipitated by adding $500 \mu 1$ 10\% trichloroacetic acid for $20 \mathrm{~min}$ with the plates on ice. The precipitated material was discarded and the procedure was repeated twice before lysing the cells with $500 \mu \mathrm{l} 0.5 \mathrm{M} \mathrm{NaOH}$ and $0.5 \%$ Triton X-100/well. Radioactivity was monitored in a $\beta$-counter. Apoptosis was detected by using the Cell Death Detection ELISA Kit (Roche Molecular Biochemicals), according to the manufacturer's instructions. Alternatively, apoptosis was analyzed by poly(ADP-ribose) polymerase (PARP) expression and cleavage was detected by western blot

Published by Bioscientifica Ltd. 
analysis. As a positive apoptosis control cells were incubated with $0.1 \mu \mathrm{g} / \mathrm{ml}$ camptothecin.

\section{Colony formation assay}

sHPT-1 parathyroid tumor cells $\left(2 \times 10^{5}\right)$ were distributed onto 35-mm dishes in DMEM/10\% fetal bovine serum (Sigma) and transfected in triplicates using FuGENE 6

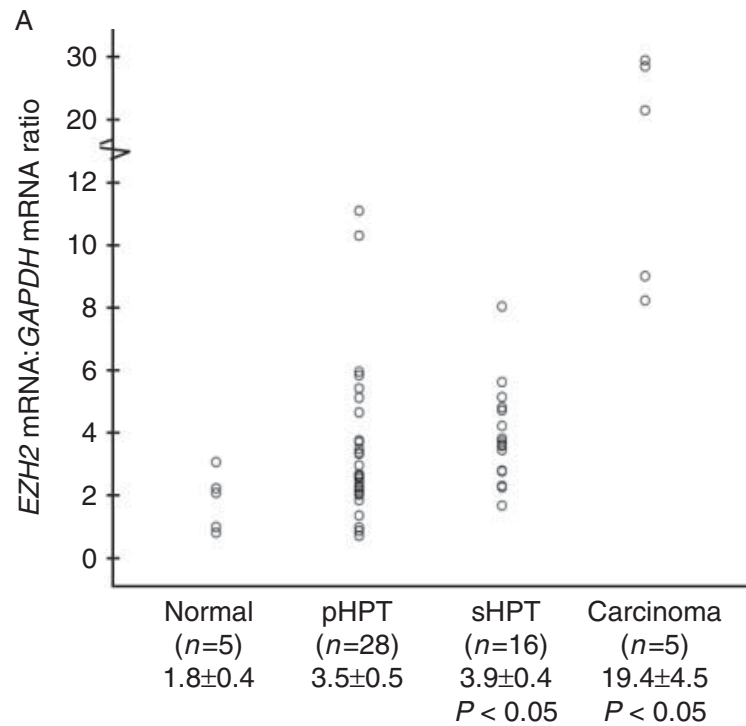

B
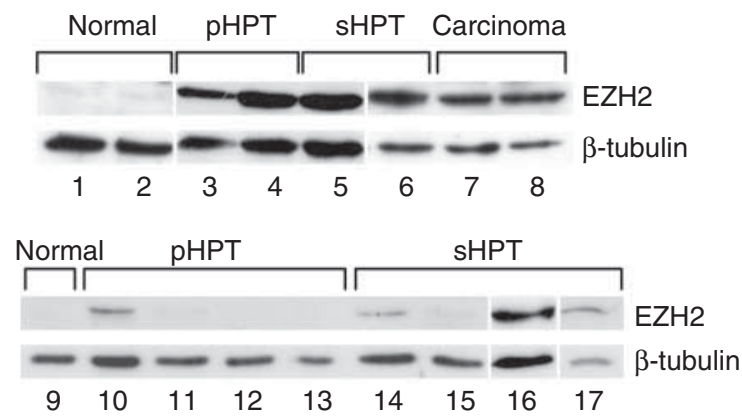

C

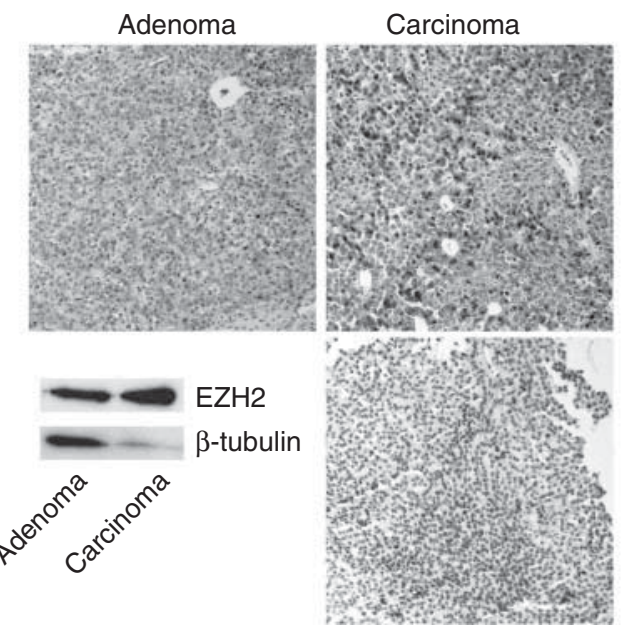

http://erc.endocrinology-journals.org DOI: 10.1530/ERC-13-0497

(C) 2014 Society for Endocrinology Printed in Great Britain transfection reagent (Roche Diagnostics) with $1 \mu \mathrm{g}$ of control vectors or $E Z H 2$ shRNA vectors (Fussbroich et al. 2011). After $24 \mathrm{~h}$, cells were seeded at $4 \times 10^{3}$ in six-well plates and the following day $60 \mu \mathrm{g} / \mathrm{ml}$ Hygromycin B were added to the culture medium. After 8 days, the selected cells were fixed with $10 \%$ acetic acid/10\% methanol and stained with $0.4 \%$ crystal violet and the visible colonies were photographed. To monitor the effects of the shRNAs, the vectors were transiently transfected and protein extracts were prepared after $72 \mathrm{~h}$ followed by western blotting analysis.

\section{Western blotting}

Protein was extracted using Cytobuster protein extraction reagent (Merck Millipore) supplemented with Complete mini protease inhibitor cocktail tablets (Roche Diagnostics). Primary antibodies used were anti-EZH2 mouse MAB (17-662, Millipore) or EZH2 rabbit monoclonal D2C9 (5246, Cell Signaling Technology, Danvers, MA, USA), antiactive- $\beta$-catenin (van Noort et al. 2002; Upstate, Lake Placid, NY, USA, \#05-665), anti-PARP rabbit polyclonal antibody (AB16661, Millipore), and anti- $\beta$-tubulin rabbit polyclonal antibody (sc-9104, Santa Cruz). After incubation with the appropriate secondary antibody, bands were visualized using the enhanced chemiluminescence system (GE Healthcare).

\section{Immunohistochemistry}

Paraffin-embedded specimens were stained as described (Björklund et al. 2007b) using an anti-EZH2 rabbit MAB (Cell Signaling Technology, Inc., EZH2 (D2C9), catalog no. 5246).

\section{Statistical analysis}

All data are presented as arithmetical mean \pm s.E.M. Paired and unpaired $t$-test and Spearman's rank correlation were

\section{Figure 1}

EZH2 mRNA and protein expression in hyperparathyroid tumors. (A) Realtime quantitative RT-PCR analysis of EZH2 in normal parathyroid tissues and parathyroid tumors. pHPT denotes parathyroid adenomas and sHPT secondary hyperplastic parathyroid glands. The relative expression level of the one normal parathyroid tissue that was obtained from glands inadvertently removed in conjunction with thyroid surgery was arbitrary set to 1.0. The four normal parathyroid gland biopsies from HPT patients displayed relative $E Z H 2$ expression levels of $0.8,2.1,2.2$, and 3.1. (B) Western blotting analysis of EZH2. Tumors with relatively high mRNA levels (upper panel) or with mRNA levels in the normal range (lower panel). Samples no. 5 , $7,8,14$, and 15 displayed $E Z H 2$ gene amplification. (C) Immunohistochemical analysis of EZH2. Paraffin-embedded sections were stained using a rabbit MAB (two upper panels) or without primary antibody (lower panel right). Western blotting of the same specimens is also shown.

Published by Bioscientifica Ltd 
used for statistical analysis. Statistical calculations were made in IBM SPSS Statistics, version 21. $P<0.05$ was considered significant.

\section{Results}

$E Z H 2$ is overexpressed and the gene amplified in a subset of parathyroid tumors regardless of hyperparathyroid disease state

In order to analyze whether EZH2 was differentially expressed in parathyroid tumors compared with normal parathyroid tissue specimens, quantitative RT-PCR was carried out. As shown in Fig. 1A, EZH2 was generally significantly overexpressed in SHPT $(3.9 \pm 0.4)$ tumors and most apparent in parathyroid carcinoma $(19.4 \pm 4.5)$, when compared with normal parathyroid tissues $(1.8 \pm 0.4)$. For parathyroid adenomas, the mean value did not reach significance (pHPT: $3.5 \pm 0.5$ ), but 11 tumors showed higher mRNA levels than the highest expressing normal tissue. EZH2 was significantly overexpressed in the parathyroid carcinomas compared with the adenomas and secondary hyperplastic parathyroid glands. No correlations between EZH2 mRNA expression level and gland weight, serum PTH, serum calcium, or serum creatinine were found. Furthermore, western blotting analysis showed prominently increased protein expression of EZH2 in parathyroid tumors with relatively high mRNA levels (Fig. 1B, upper panel). EZH2 protein expression could also be detected in some pHPT and sHPT tumors with the relative EZH2 mRNA levels in the normal range (Fig. 1B, lower panel). Immunohistochemistry analysis of EZH2 revealed prominent cytoplasmic and nuclear immunoreactivity. An evenly stained level for most cells in all areas was observed in the adenoma that appeared more heterogenous in the carcinoma (Fig. 1C). mRNA levels were also determined for the PCR2 components EED and SUZ12. Only SUZ12 showed significantly different expression, with a generally reduced level in secondary hyperplastic parathyroid glands (Fig. 2). The three parathyroid carcinomas with highest EZH2 expression also showed overexpression of $E E D$, and the two parathyroid adenomas with the highest EZH2 showed highest expression of SUZ12. The very low expression of $E Z H 2$ in the normal parathyroid tissue specimens was not associated with DNA methylation of the EZH2 CpG island, as determined by quantitative bisulfite pyrosequencing analysis (data not shown).

Real-time quantitative PCR revealed relative amplification of the EZH2 gene (four gene copies) in $29 \%$ of the pHPT tumors, $50 \%$ of the sHPT tumors, and $60 \%$ of the
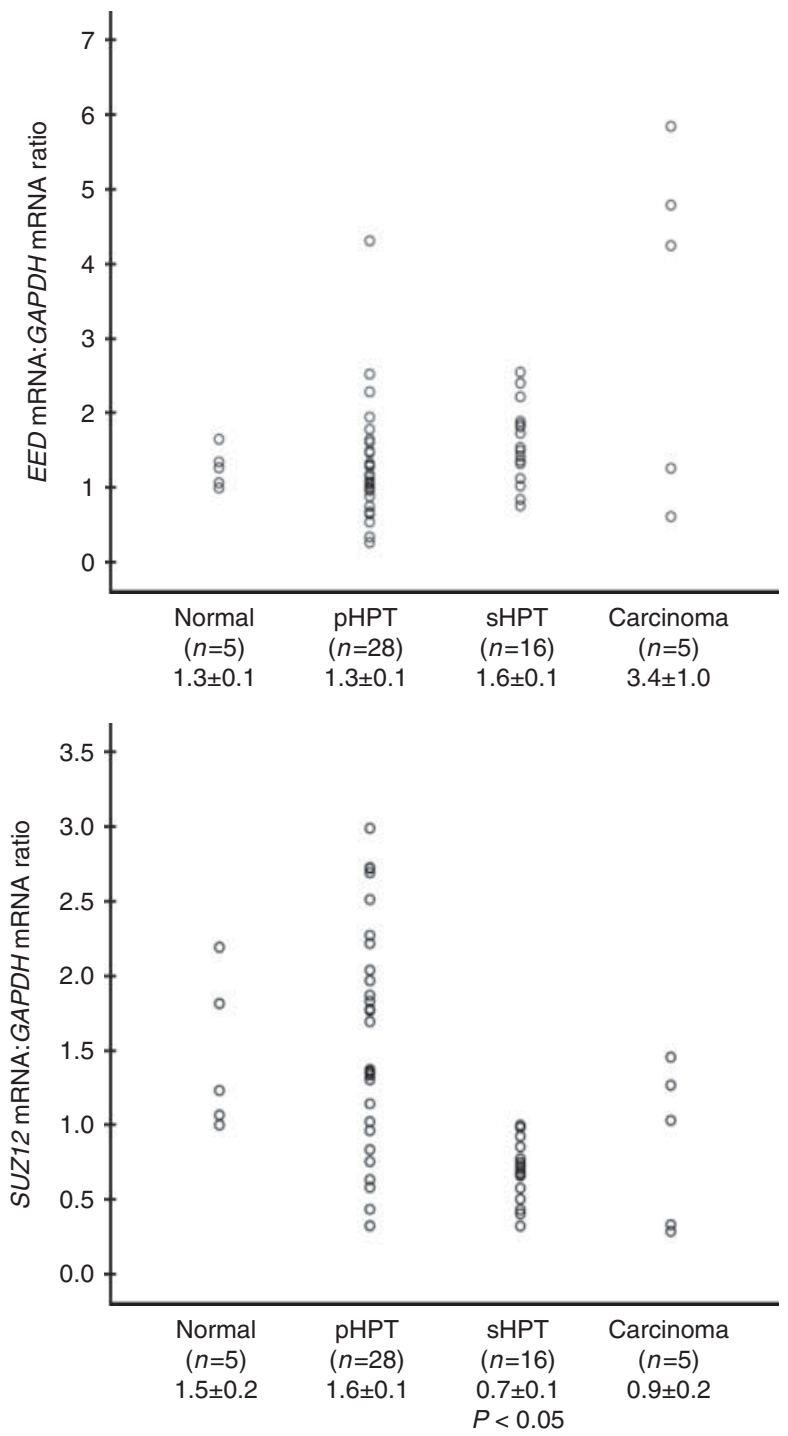

Figure 2

Real-time quantitative RT-PCR analysis of PRC2 components EED and SUZ12.

parathyroid carcinomas (Table 1). Thirteen out of the 19 tumors with gene amplification displayed overexpression of EZH2 mRNA and the three tumors analyzed by western blotting showed prominently increased protein expression (Fig. 1B, upper panel). Two tumors included in the western blotting analysis with gene amplification, and EZH2 mRNA expression within the normal range showed weakly detectable or undetectable EZH2 protein level respectively compared with normal tissue (Fig. 1B, lower panel). Some of the benign tumors and two of the carcinomas showed higher EZH2 mRNA expression level without gene amplification. No correlations between EZH2 gene copy number and gland weight, serum PTH, serum calcium, or serum creatinine were found.

Published by Bioscientifica Ltd. 
Table 1 Copy-number variation of $E Z H 2$ in parathyroid tumors

\begin{tabular}{|c|c|c|c|}
\hline Tumor type & $\begin{array}{c}\text { Number of } \\
\text { tumors with EZH2 } \\
\text { amplification }^{\mathrm{a}}\end{array}$ & $\begin{array}{c}\text { Total number } \\
\text { of tumors } \\
\text { analyzed }\end{array}$ & $\begin{array}{c}\text { Percentage of } \\
\text { tumors with EZH2 } \\
\text { amplification (\%) }\end{array}$ \\
\hline pHPT & 8 & 28 & 29 \\
\hline sHPT & 8 & 16 & 50 \\
\hline Carcinomas & 3 & 5 & 60 \\
\hline
\end{tabular}

${ }^{a}$ All displayed four gene copies.

\section{Maintained expression of EZH2 is required for parathyroid tumor cell growth}

Next, we investigated whether EZH2 could control growth of parathyroid tumor cells. siRNA to EZH2 significantly inhibited proliferation and reduced cell viability of the human parathyroid tumor cell line sHPT-1, as determined by ${ }^{3} \mathrm{H}$-thymidine incorporation and WST-1 incubation
(Fig. 3A). The sHPT-1 cell line expresses parathyroid hormone and was established from a hyperplastic parathyroid gland removed at operation of a patient with sHPT (Björklund et al. 2007a). Colony formation assay was then performed to further evaluate a growth regulatory role of EZH2. sHPT-1 cells were stably transfected with EZH2 shRNA expression vectors or control vectors (Fussbroich et al. 2011). The results showed a prominent reduction in the colony formation capacity in EZH2 shRNA-expressed cells compared with control shRNAs, only a few very small colonies were seen in EZH2 shRNA-expressing cells (Fig. 3C). Thus, EZH2 depletion blocked the growth of parathyroid tumor cells. No apparent effect on apoptosis was detected after depletion of $E Z H 2$ with siRNA or shRNA expression vectors, as determined by quantifying cytoplasmic histone-associated-DNA-fragments or by examining PARP protein expression and cleavage (Fig. 3B and D).
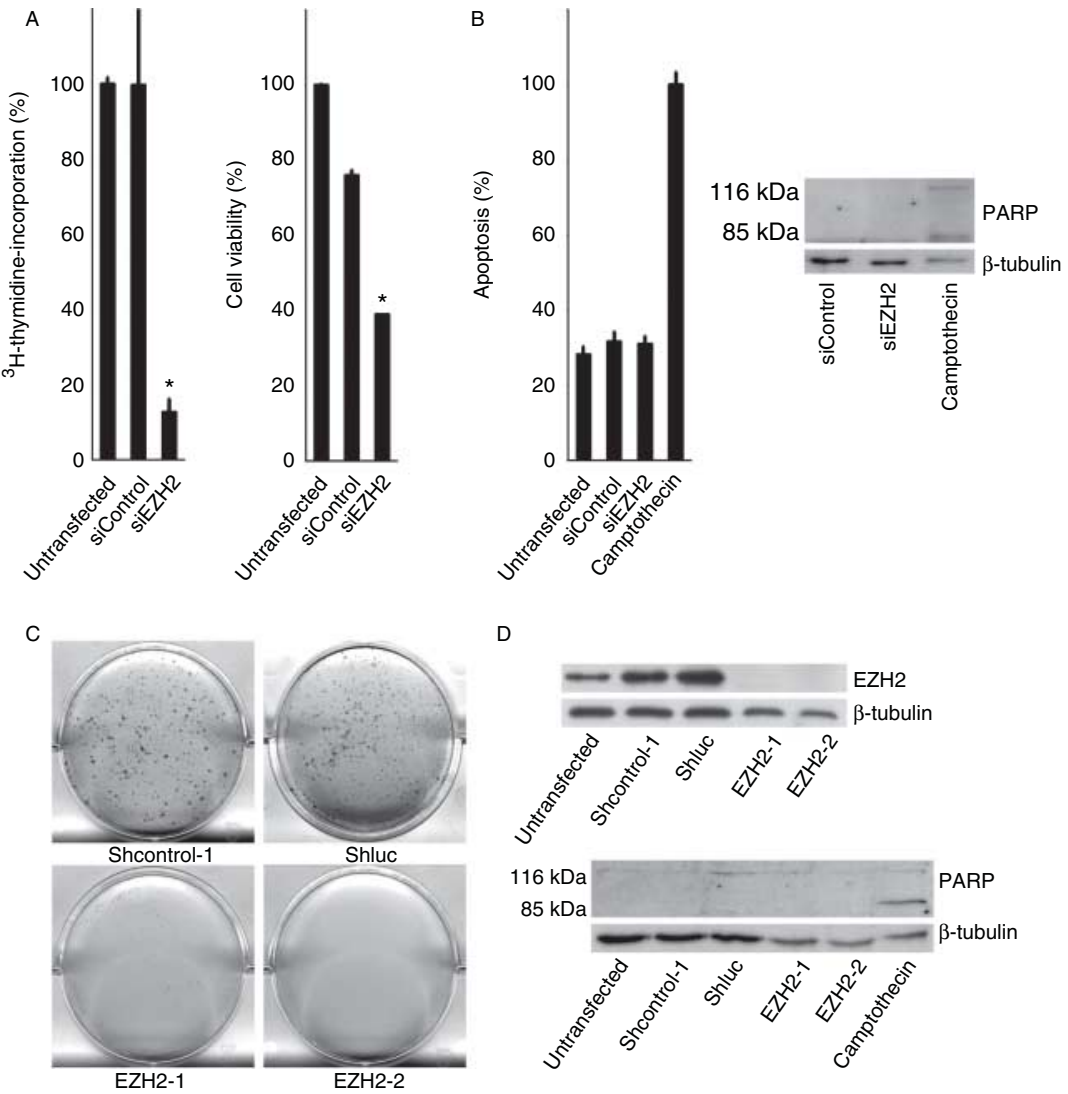

D

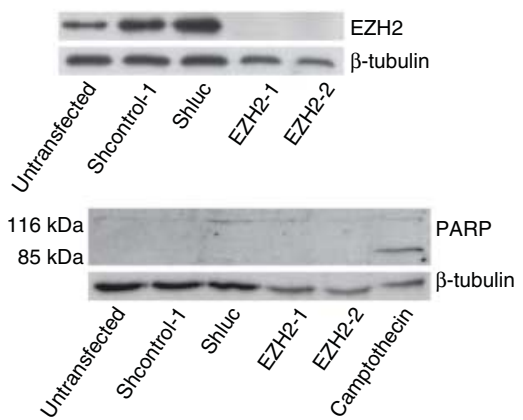

Figure 3

Cellular proliferation, viability, colony formation, and apoptosis on EZH2 knockdown. Transient transfection of siControl and siEZH2 to the SHPT-1 parathyroid tumor cell line. Efficient knockdown of EZH2 was obtained at the mRNA (4C) and protein level (Svedlund et al. 2012). (A) Effects on cell proliferation and cell viability were determined by ${ }^{3} \mathrm{H}$-thymidine incorporation (left panel) and WST-1 incubation (right panel).

(B) Effects on apoptosis were analyzed by quantifying cytoplasmic

histone-associated-DNA-fragments (left panel) and induction of PARP expression and cleavage (right panel). (C) Colony formation assay. sHPT-1 cells were stably transfected with plasmids expressing two different shRNAs to EZH2 (pCEP-shEZH2-1, pCEP-shEZH2-2) or two control shRNAs (pCEP-shluc, pCEP-shcontrol-1). (D) Western blotting after transient transfection of the shRNA vectors showing EZH2 expression (upper panel) and induction of PARP expression and cleavage (lower panel).

Published by Bioscientifica Ltd. 


\section{EZH2 contributes to Wnt/ $\beta$-catenin signaling in parathyroid tumor cells}

It has been reported that $\mathrm{EZH} 2$ can regulate $\mathrm{Wnt} / \beta$-catenin signaling indirectly by epigenetic repression of several Wnt antagonists, including the growth-suppressive Axin2, leading to enhanced level of transcriptionally active (nonphosphorylated) $\beta$-catenin (Cheng et al. 2011). In sHPT-1 parathyroid tumor cells, AXIN2 expression was indeed increased under conditions with decreased EZH2 level, and expression of CYCLIN D1, known to be regulated by $\beta$-catenin in parathyroid cells (Björklund et al. 2007a), was significantly reduced (Fig. 4A). Furthermore using an antibody specific for transcriptionally active (nonphosphorylated) $\beta$-catenin (van Noort et al. 2002), a reduced level of active $\beta$-catenin (15\%) was observed in siEZH2-transfected sHPT-1 cells (Fig. 4B and C) compared with siControl (100\%). As expected (Björklund et al. 2007c), siRNA to LRP5 also reduced the active $\beta$-catenin level (30\%) and furthermore $\beta$-catenin was undetectable after siEZH2 + siLRP5 cotransfection. Thus, EZH2 contributed to the total level of active $\beta$-catenin together with LRP5 in the parathyroid tumor cells.

\section{Discussion}

EZH2 gene amplification was observed in 19 out of 49 analyzed parathyroid tumors and was related to EZH2 mRNA overexpression in 13 of these 19 tumors (Fig. 5, for summary and possible mechanisms). Importantly, western blotting analysis showed that it was possible to detect EZH2 expression also in tumors with or without gene amplification and with an EZH2 mRNA expression level within the one for normal tissues. This may imply tight regulation of EZH2 mRNA levels and perhaps relatively long half-life for EZH2 proteins in a subset of tumors. Some of the benign tumors and two of the carcinomas showed higher EZH2 mRNA expression level without gene amplification, suggesting the involvement of other more indirect mechanisms. The c-Myc oncoprotein has recently been shown to positively regulate EZH2 expression in early prostatic neoplasia, both directly as a transcriptional activator and indirectly by repression of miR-26a and miR26b, that regulate EZH2 mRNA at the post-transcriptional level (Koh et al. 2011). This mechanism may apply to the parathyroid as $c-M y c$ overexpression has been reported for a subset of parathyroid adenomas and hyperplastic parathyroid glands from patients with HPT secondary to uremia (Björklund et al. 2007b). To our knowledge, EZH2 gene amplification presents the first genetic aberration
A

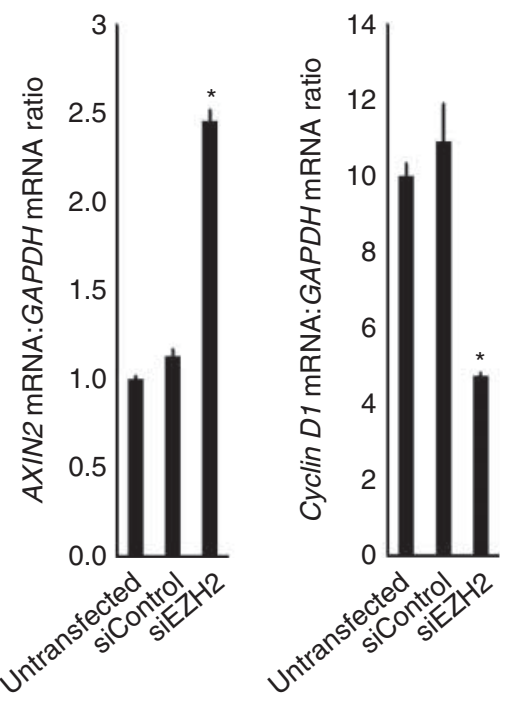

B

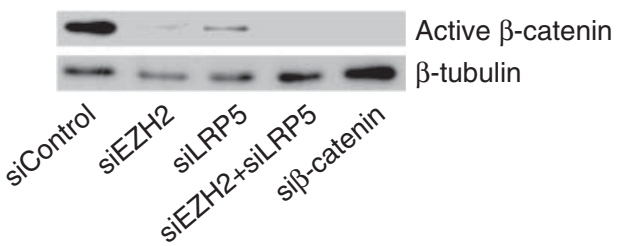

C
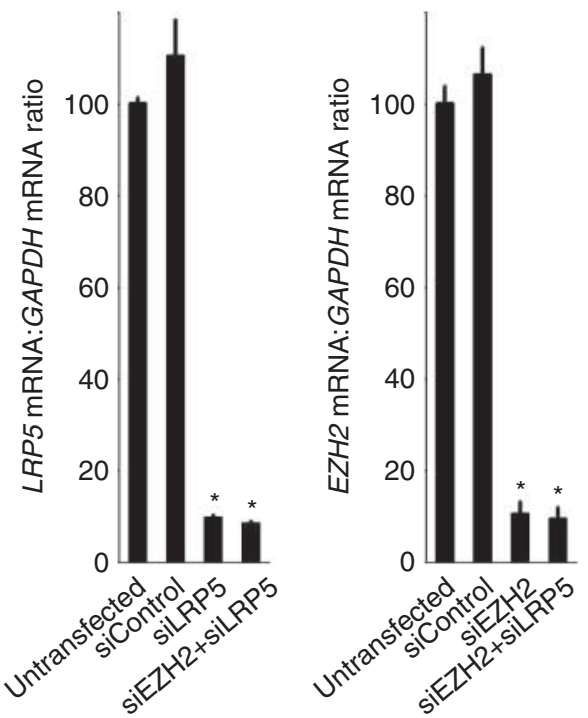

Figure 4

Wnt/ $\beta$-catenin signaling on EZH2 knockdown. (A) Transient transfection of siControl and siEZH2 to the SHPT-1 parathyroid tumor cell line and determination of AXIN2 (left panel) and CYCLIN D1 (right panel) expression by real-time quantitative RT-PCR analysis. (B) Western blotting analysis of transiently siRNA-transfected sHPT-1 cells using the anti-active $\beta$-catenin antibody. This antibody is specific for transcriptionally active (nonphosphorylated) $\beta$-catenin (van Noort et al. 2002). (C) Transient transfection of siControl, siLRP5, and SiEZH2 and determination of LRP5 and EZH2 relative mRNA expression by real-time quantitative RT-PCR analysis. 


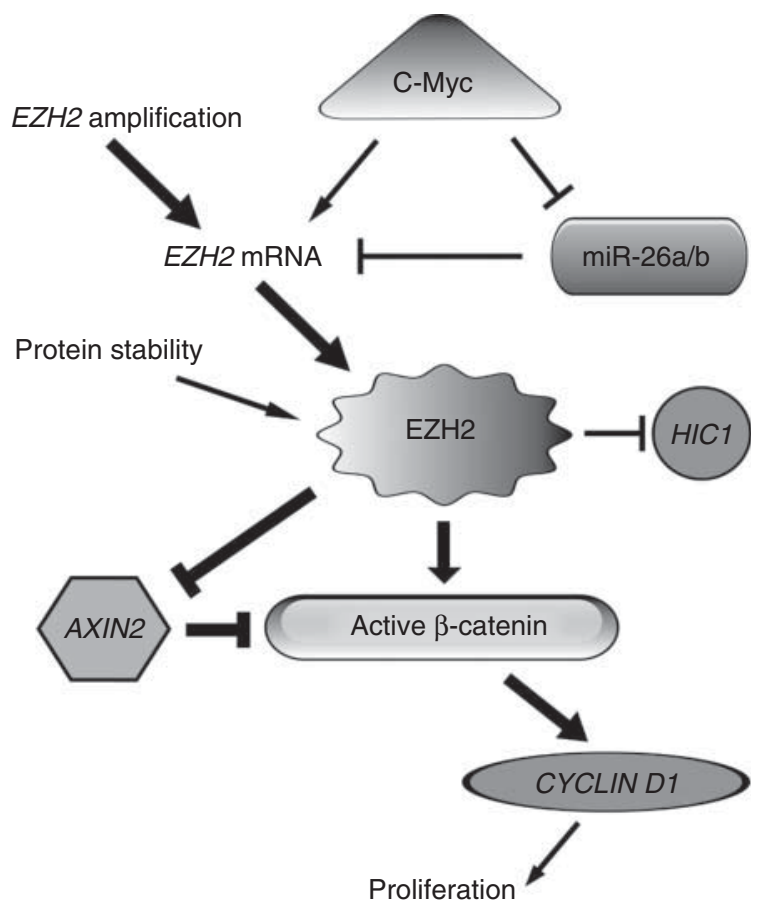

Figure 5

Summary of the results and possible mechanisms. EZH2 protein overexpression caused by $E Z H 2$ gene amplification and increased mRNA level or by indirect mechanisms such as EZH2 protein stability and by direct or indirect regulation of $E Z H 2$ gene expression by the c-Myc oncoprotein (Björklund et al. 2007b, Koh et al. 2011). Deregulated increased EZH2 protein level could result in activation of the $\mathrm{Wnt} / \beta$-catenin signaling pathway by repression of AXIN2 (Cheng et al. 2011) and accumulation of transcriptionally active (nonphosphorylated) $\beta$-catenin, with increased expression of the $\beta$-catenin target gene CYCLIN D1 (Björklund et al. 2007a) and proliferation. Repression of the HIC1 tumor suppressor gene in parathyroid tumors involved EZH2 and H3K27 methylation (Svedlund et al. 2012).

common to a subset of parathyroid adenomas, secondary hyperplastic parathyroid glands, and parathyroid carcinomas. This further supports the possibility of a common pathway in parathyroid tumor development (Svedlund et al. 2012). Interestingly, somatic EZH2 Y641N mutations were recently observed in parathyroid adenomas (Cromer et al. 2012), albeit at a very low frequency (two out of 193). Mutations at Y641 may result in enhanced catalytic methyltransferase activity and it seems that heterozygous mutations work in conjunction with WT EZH2 to increase H3K27me3. This may be functionally equivalent to overexpression of EZH2 (Sneeringer et al. 2010, Yap et al. 2011). EZH2 can also act as a coactivator, independent of its role as repressor in the PRC2 complex and this activity of $E Z H 2$ is oncogenic as demonstrated in prostate cancer cells (Xu et al. 2012).

Downregulation of EZH2 inhibited proliferation and growth of sHPT-1 parathyroid tumor cells, as previously observed for LRP5 depletion and reduced level of nonphosphorylated active $\beta$-catenin (Björklund et al. 2007c). This in line with recent results showing reduced proliferation of primary parathyroid tumor cells and sHPT-1 cells by the global histone methyltransferase inhibitor 3-deazaneplanocin A (Miranda et al. 2009, Svedlund et al. 2012), which affects several different repressive histone modifications but also depletes EZH2 (Fiskus et al. 2009). Overexpression of EZH2 may result in deregulated expression of a large number of target genes, some of which contributes to parathyroid tumorigenesis. The tumor suppressor gene HIC1 likely presents such a target gene since the aberrant underexpression of HIC1, observed in both benign and malignant parathyroid tumors, involved repressive H3K27me3 modifications and EZH2 (Svedlund et al. 2012).

EZH2 may play a crucial role in metastatic parathyroid disease, as the gene was found to be significantly more expressed in the carcinomas in comparison with the benign parathyroid tumors.

Furthermore, it will be of interest to investigate whether MEN1 gene inactivation and EZH2 overexpression is functionally redundant or if both events contribute to parathyroid tumor development. It has been demonstrated that MENIN, encoded by the MEN1 gene, can repress transcription through H3K27 methylation, in suppression of lung adenocarcinoma (Gao et al. 2009).

\section{Declaration of interest}

The authors declare that there is no conflict of interest that could be perceived as prejudicing the impartiality of the research reported.

\section{Funding}

This research was supported by grants from The Swedish Research Council, The Swedish Cancer Society, and Lions Fund for Cancer Research.

\section{Acknowledgements}

The authors thank Dr Felix Hoppe-Seyler for making the shRNA EZH2 and shRNA control expression plasmids available to us.

\section{References}

Åkerstrom G \& Hellman P 2004 Primary hyperparathyroidism. Current Opinion in Oncology 16 1-7.

Björklund P \& Åkerstrom G 2009 Molecular genetics of parathyroid disease. World Journal of Surgery 33 2224-2233. (doi:10.1007/s00268-009-0022-6)

Björklund P, Åkerström G \& Westin G 2007a Activated $\beta$-catenin in the novel human parathyroid tumor cell line sHPT-1. Biochemical and Biophysical Research Communications 352 532-536. (doi:10.1016/ j.bbrc.2006.11.056) 
Björklund P, Åkerström G \& Westin G $2007 b$ Accumulation of nonphosphorylated $\beta$-catenin and c-myc in primary and uremic secondary hyperparathyroid tumors. Journal of Clinical Endocrinology and Metabolism 92 338-344. (doi:10.1210/jc.2006-1197)

Björklund P, Åkerström G \& Westin G 2007c An LRP5 receptor with internal deletion in hyperparathyroid tumors with implications for deregulated WNT/B-catenin signaling. PLoS Medicine 4 e328. (doi:10.1371/journal.pmed.0040328)

Bracken AP, Pasini D, Capra M, Prosperini E, Colli E \& Helin K 2003 EZH2 is downstream of the pRB-E2F pathway, essential for proliferation and amplified in cancer. EMBO Journal 22 5323-5335. (doi:10.1093/emboj/cdg542)

Chang CJ \& Hung MC 2012 The role of EZH2 in tumor progression. British Journal of Cancer 106 243-247. (doi:10.1038/bjc.2011.551)

Chase A \& Cross NC 2011 Aberrations of EZH2 in cancer. Clinical Cancer Research 17 2613-2618. (doi:10.1158/1078-0432.CCR-10-2156)

Cheng AS, Lau SS, Chen Y, Kondo Y, Li MS, Feng H, Ching AK, Cheung KF, Wong HK, Tong JH et al. $2011 \mathrm{EZH2-mediated} \mathrm{concordant} \mathrm{repression} \mathrm{of}$ Wnt antagonists promotes $\beta$-catenin-dependent hepatocarcinogenesis. Cancer Research 71 4028-4039. (doi:10.1158/0008-5472.CAN-10-3342)

Clevers H \& Nusse R 2012 Wnt/ $\beta$-catenin signaling and disease. Cell 149 1192-1205. (doi:10.1016/j.cell.2012.05.012)

Costa-Guda J \& Arnold A 2013 Genetic and epigenetic changes in sporadic endocrine tumors: parathyroid tumors. Molecular and Cellular Endocrinology [in press]. (doi:10.1016/j.mce.2013.09.005)

Cromer MK, Starker LF, Choi M, Udelsman R, Nelson-Williams C, Lifton RP \& Carling T 2012 Identification of somatic mutations in parathyroid tumors using whole-exome sequencing. Journal of Clinical Endocrinology and Metabolism 97 E1774-E1781. (doi:10.1210/jc.2012-1743)

Fiskus W, Wang Y, Sreekumar A, Buckley KM, Shi H, Jillella A, Ustun C, Rao R, Fernandez P, Chen J et al. 2009 Combined epigenetic therapy with the histone methyltransferase EZH2 inhibitor 3-deazaneplanocin A and the histone deacetylase inhibitor panobinostat against human AML cells. Blood 114 2733-2743. (doi:10.1182/blood-2009-03-213496)

Fussbroich B, Wagener N, Macher-Goeppinger S, Benner A, Fälth M, Sültmann H, Holzer A, Hoppe-Seyler K \& Hoppe-Seyler F 2011 EZH2 depletion blocks the proliferation of colon cancer cells. PLOS ONE 6 e21651. (doi:10.1371/journal.pone.0021651)

Gao SB, Feng ZJ, Xu B, Wu Y, Yin P, Yang Y, Hua X \& Jin GH 2009 Suppression of lung adenocarcinoma through menin and polycomb gene-mediated repression of growth factor pleiotrophin. Oncogene $\mathbf{2 8}$ 4095-4104. (doi:10.1038/onc.2009.273)

Koh CM, Iwata T, Zheng Q Bethel C, Yegnasubramanian S \& De Marxo AM 2011 Myc enforces overexpression of EZH2 in early prostatic neoplasia via transcriptional and post-transcriptional mechanisms. Oncotarget 2 669-683.

Lemos MC \& Thakker RV 2008 Multiple endocrine neoplasia type 1 (MEN1): analysis of 1336 mutations reported in the first decade following identification of the gene. Human Mutation 29 22-32. (doi:10.1002/humu.20605)

Li X, Gonzalez ME, Toy K, Filzen T, Merajver SD \& Kleer CG 2009 Targeted overexpression of EZH2 in the mammary gland disrupts ductal morphogenesis and causes epithelial hyperplasia. American Journal of Pathology 175 1246-1254. (doi:10.2353/ajpath.2009.090042)

Lin SY, Xia W, Wang JC, Kwong KY, Spohn B, Wen Y, Pestell RG \& Hung MC $2000 \beta$-Catenin, a novel prognostic marker for breast cancer: its roles in cyclin D1 expression and cancer progression. PNAS 97 4262-4266. (doi:10.1073/pnas.060025397)

Margueron R \& Reinberg D 2011 The polycomb complex PRC2 and its mark in life. Nature 469 343-349. (doi:10.1038/nature09784)

Marx SJ 2000 Hyperparathyroid and hypoparathyroid disorders. New England Journal of Medicine 343 1863-1875. (doi:10.1056/ NEJM200012213432508)
Miranda TB, Cortez CC, Yoo CB, Liang G, Abe M, Kelly TK, Marquez VE \& Jones PA 2009 DZNep is a global histone methylation inhibitor that reactivates developmental genes not silenced by DNA methylation. Molecular Cancer Therapeutics 8 1579-1588. (doi:10.1158/1535-7163. MCT-09-0013)

Newey PJ, Nesbit MA, Rimmer AJ, Attar M, Head RT, Christie PT, Gorvin CM, Stechman M, Gregory L, Mihai R et al. 2012 Wholeexome sequencing studies of nonhereditary (sporadic) parathyroid adenomas. Journal of Clinical Endocrinology and Metabolism 97 E1995-E2005. (doi:10.1210/jc.2012-2303)

van Noort M, Meeldijk J, van der Zee R, Destree O \& Clevers H 2002 Wnt signaling controls the phosphorylation status of $\beta$-catenin. Journal of Biological Chemistry 277 17901-17905. (doi:10.1074/jbc.M111635200)

O'Meara MM \& Simon JA 2012 Inner workings and regulatory inputs that control polycomb repressive complex 2. Chromosoma 121 221-234. (doi:10.1007/s00412-012-0361-1)

Saramaki OR, Tammela TL, Martikainen PM, Vessella RL \& Visakorpi T 2006 The gene for polycomb group protein enhancer of zeste homolog 2 (EZH2) is amplified in late-stage prostate cancer. Genes, Chromosomes \& Cancer 45 639-645. (doi:10.1002/gcc.20327)

Sharretts JM \& Simonds WF 2010 Clinical and molecular genetics of parathyroid neoplasms. Best Practice \& Research. Clinical Endocrinology \& Metabolism 24 491-502. (doi:10.1016/j.beem.2010.01.003)

Shi B, Liang J, Yang X, Wang Y, Zhao Y, Wu H, Sun L, Zhang Y, Chen Y, Li R et al. 2007 Integration of estrogen and Wnt signaling circuits by the polycomb group protein EZH2 in breast cancer cells. Molecular and Cellular Biology 27 5105-5119. (doi:10.1128/MCB.00162-07)

Shtutman M, Zhurinsky J, Simcha I, Albanese C, D’Amico M, Pestell R \& Ben-Ze'ev A 1999 The cyclin D1 gene is a target of the $\beta$-catenin/LEF-1 pathway. PNAS 96 5522-5527. (doi:10.1073/pnas.96.10.5522)

Sneeringer CJ, Scott MP, Kuntz KW, Knutson SK, Pollock RM, Richon VM \& Copeland RA 2010 Coordinated activities of wild-type plus mutant EZH2 drive tumor-associated hypertrimethylation of lysine 27 on histone H3 (H3K27) in human B-cell lymphomas. PNAS 107 20980-20985. (doi:10.1073/pnas.1012525107)

Svedlund J, Aurén M, Sundström M, Dralle H, Åkerström G, Björklund P \& Westin G 2010 Aberrant WNT//-catenin signaling in parathyroid carcinoma. Molecular Cancer 9 294. (doi:10.1186/1476-4598-9-294)

Svedlund J, Koskinen Edblom S, Marquez VE, Åkerström G, Björklund P \& Westin G 2012 Hypermethylated in cancer 1 (HIC1), a tumor suppressor gene epigenetically deregulated in hyperparathyroid tumors by histone $\mathrm{H} 3$ lysine modification. Journal of Clinical Endocrinology and Metabolism 97 E1307-E1315. (doi:10.1210/jc.2011-3136)

Westin G, Björklund P \& Åkerstrom G 2009 Molecular genetics of parathyroid disease. World Journal of Surgery 33 2224-2233. (doi:10.1007/s00268-009-0022-6)

Woodard GE, Lin L, Zhang JH, Agarwal SK, Marx SJ \& Simonds WF 2005 Parafibromin, product of the hyperparathyroidism-jaw tumor syndrome gene HRPT2, regulates cyclin D1/PRAD1 expression. Oncogene 24 1272-1276. (doi:10.1038/sj.onc.1208274)

Xu K, Wu ZJ, Groner AC, He HH, Cai C, Lis RT, Wu X, Stack EC, Loda M, Liu T et al. $2012 \mathrm{EZH} 2$ oncogenic activity in castration-resistant prostate cancer cells is polycomb-independent. Science $\mathbf{3 3 8}$ 1465-1469. (doi:10.1126/science.1227604)

Yap DB, Chu J, Berg T, Schapira M, Cheng SW, Moradian A, Morin RD, Mungall AJ, Meissner B, Boyle M et al. 2011 Somatic mutations at EZH2 Y641 act dominantly through a mechanism of selectively altered PRC2 catalytic activity, to increase H3K27 trimethylation. Blood $\mathbf{1 1 7}$ 2451-2459. (doi:10.1182/blood-2010-11-321208)

Received in final form 26 November 2013

Accepted 29 November 2013

Made available online as an Accepted Preprint

29 November 2013 http://erc.endocrinology-journals.org DOI: 10.1530/ERC-13-0497
(C) 2014 Society for Endocrinology Printed in Great Britain 